\title{
BIOSPECKLE LASER TO MONITOR THE GERMINATION OF ANGICO-VERMELHO SEEDS
}

\section{José Luís Contado}

Federal University of Lavras (UFLA), Dept. of Food Science (DCA), Campus, P.O. Box 3037, ZIP Code 37200-000, Lavras, MG, Brazil

Corresponding author: jcontado@ufla.br

\section{Caroline de Faria Silva}

Federal University of Lavras (UFLA), Dept. of Automation (DAT), Campus, P.O. Box 3037, ZIP Code 37200-000, Lavras, MG, Brazil

\section{Roberto Alves Braga Júnior}

Federal University of Lavras (UFLA), Dept. of Automation (DAT), Campus, P.O. Box 3037, ZIP Code 37200-000, Lavras, MG, Brazil

\begin{abstract}
Seed viability is an important parameter in its germination and in the establishment of seedlings, as well as for maintaining a seed bank, mainly for forest seeds, since they are responsible for the maintenance and perpetuation of plant communities and are a basic input for ecosystem recovery and conservation programs. To assess germination, traditional techniques use hundreds of seeds in a destructive manner, obtaining results after many days and can express the analyst's subjectivity. The use of the Biospeckle Laser to monitor seed germination allows the analysis to be objective, fast, non-invasive, and automated analysis. This work proposed to measure the viability of Angico-Vermelho seeds during the first 72 hours of germination using the Biospeckle Laser with numerical analysis. The results obtained in the first experiment allowed monitoring of biological activity throughout the 72 hours of germination, showing high cell activity in the embryo region already in the first 4 hours of germination. In the second experiment, the results showed greater biological activity in the mature seeds when compared to immature ones during the first 4 hours of germination, also detailing the biological activity in different areas of the Angico-Vermelho seed, reporting a greater biological activity in the embryonic axis region when compared to the endosperm. In conclusion, the Biospeckle Laser technique with numerical AVD analysis can be used to analyze the germination of of $A$. colubrina already in the first 4 hours of germination, dispensing with traditional methods. This technique allows to study the seed germination in different regions and at different times.
\end{abstract}

Index terms: BSL, Biological activity, Forest seeds.

Received: March, 17, 2020 - Accepted: May, 12, 2020

\section{INTRODUCTION}

Seed viability is an important parameter in its germination and in the establishment of seedlings, for both planting and maintaining a seed bank. Many methods are employed to analyze seed viability, including traditional germination, vigor, tetrazolium tests, and others. These analyses are conducted in a laboratory under controlled conditions and use hundreds of seeds in a destructive manner. The results are obtained after many days and can express the analyst's subjectivity (Fonseca and Freire, 2003). Optical techniques have been used as non-invasive, non-destructive, and non-subjective techniques, with near real-time results. The tomographic analysis employs X-rays, positron emission tomography (PET), ultrasound or magnetic resonance imaging (MRI), presenting high acceptability and efficiency (Meglinski, Burabachai and Terry, 2010). Other tomographic techniques such as micro-optrode (MOT) and optical coherence (OCT) express results in near real-time. However, MOT has the disadvantage of requiring specific oxygen sensors to control oxygen flow and avoid hypoxia stress in the seeds (Xin et al., 2013; Bradford, Côme and Corbinear, 2007; Armstrong et al., 2009). The OCT technique has low penetration into the 
sample surface, being viable only in studies on seed pathogens (Lee et al., 2011). The Speckle Laser Dynamic technique is prominent among those that employ laser and is denominated biospeckle laser when used in the analysis of biological materials (Rabal and Braga, 2008).

Biospeckle Laser has become a valuable tool in several areas of knowledge, especially in biology, agronomy, and biomedicine. It is a phenomenon of optical interference that occurs when a material is illuminated by a coherent light, which is dispersed over a surface (Rabal and Braga, 2008). When applied to dynamic surfaces, a continuous change in optical interference patterns is observed (Braga et al., 2001; Rabal and Braga, 2008; Zdunek et al., 2014). The method also has the advantage of being non-destructive and non-invasive. Specifically for seed analysis, several studies have related the activity presented by the Biospeckle Laser with the quality, viability, deterioration, and germinative potential of commercial seeds, such as beans (Braga et al., 2001; Moreira et al., 2002; Braga et al., 2003; Braga Junior et al., 2005; Rodrigues et al., 2005; Nascimento et al., 2007; Rodrigues et al., 2007), corn (Braga et al., 2001; Peixoto et al., 2018), and coffee (Vivas, 2016). In the works with coffee seed germination, the authors observed that the results obtained by the Biospeckle laser were as efficient as the results of the tetrazolium, with the advantage of not being destructive and expressing the results in near real-time (Vivas, 2016). As for works involving biospeckle and germination of Brazilian forest seeds, there are few publications with seeds of purple ipe and araça-boi (Fracarolli et al., 2010; Moura et al., 2015).

Forest seeds are responsible for maintaining and perpetuating plant communities and are a basic input in ecosystem recovery and conservation programs. Therefore, the physiological, physical, sanitary, and genetic quality of seeds directly influences the production of healthy and viable seedlings, aimed at longterm population adaptability and permanence (Parisi et al., 2019).

Anandenanthera colubrina (Vell.) Brenan, a native forest species popularly known as Angico-Vermelho, has great economic, ecological, and social importance and is distributed from the Northeast region of Brazil to Bolivia, Argentina, Paraguay, and Peru (Altschul, 1964). The high occurrence and the diverse uses attributed to Angico-Vermelho provided an intense exploration of its bark, leaf, wood, and flowers for the most diverse uses inherent to its properties, presenting an ecological importance in the afforestation of squares and parks, as well as in the recovery of degraded areas, a social importance due to the use of its bark, roots, and seeds in popular medicine, in addition to being explored for economic purposes in several sectors, such as ornamental plants, pharmaceuticals, tanneries, timber, and coal production (Vieira and Carvalho, 1994; Monteiro et al., 2005; Rodrigues et al., 2007; Lorenzi, 2014).

The disorderly exploitation of the AngicoVermelho, combined with the lack of adequate management practices and a reforestation policy aimed at replacing the exploited trees, is putting this species at risk of extinction (Rodrigues, 2005; Paes et al., 2006; Fracarolli et al., 2010). According to Silva et al. (2012), the destruction of forests leads to the loss of biodiversity and habitat for many species. Its effects also cause changes in the hydrological cycle, rainfall formation, and characteristics of a microclimate. Without the roots to absorb rainwater, unprotected soils are more susceptible to erosion. Thus, the soil loses its water infiltration capacity and stops supplying groundwater. Since it is a native species and threatened with extinction, it is necessary to undertake studies that enable the preservation of the Angico-Vermelho species.

One way to avoid the extinction of native forest species is through seed propagation (Machado and Cícero, 2002). Considering the germination process as the resumption of metabolic activities from the embryonic axis until the tegument rupture by the radicle (Bewley and Black, 1994), this physiological period becomes a critical stage of the plant biocycle because of its association with the action of several extrinsic and intrinsic factors, that is, interference in the physio-metabolic processes ((Bewley and Black, 1994, Koszo, Rinaldi and Barbedo, 2007). 
In view of the above, a study on germination in forest seeds and efficient methodologies of viability analysis becomes of fundamental importance for the preservation of $A$. colubrina (Vell.) Brenan and to ensure the use of AngicoVermelho in its economic, ecological or social importance. Thus, this work proposes to study the application of the Biospeckle Laser technique with numerical analysis for monitoring the germination of AngicoVermelho seeds for an objective, fast and automated analysis.

\section{MATERIAL AND METHODS}

We used freshly collected Angico-Vermelho seeds in the assays. In the first experiment, we disinfected eight mature Angico-Vermelho seeds in $1 \%$ sodium hypochlorite solution for 1 minute, washed them ten times in demineralized water, removed the teguments, and placed them under a screen containing agar $5.5 \%$ as substrate. These screens were fixed to the carousel of the automated device, which was located under an optical table with an anti-vibration system. The automated system consists of 4 parts: laser emission (a red diode laser, $635 \mathrm{~nm}, 10 \mathrm{~mW}$ of power) and laser capture dispersed by the seed in the form of an image (special Dino Lite camera); a computer to process and archive these images; an automated carousel system with capacity for eight seeds (controlled by an Arduino Uno microcontroller, a stepper motor, and a presence sensor) connected to this computer (Figure 1).

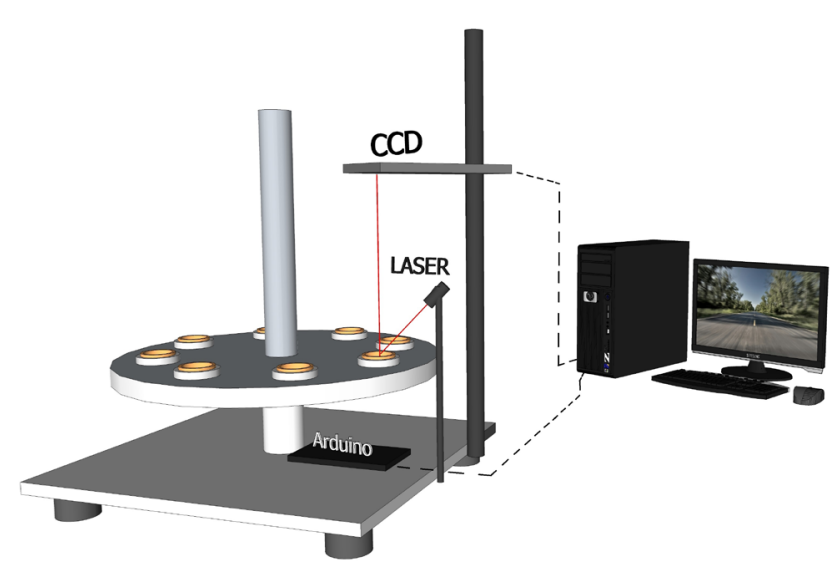

Figure 1: Photograph of the automated system.
Each seed was illuminated at an interval of four hours, during the initial 72 hours of germination, totalizing 18 collections, at a room temperature of $25{ }^{\circ} \mathrm{C}$. We obtained 128 images for each lighting. These images were processed using Octave software version 3.8.1 (Eaton et al., 2015) and the speckle patterns were obtained by the Contrast (Briers and Webster, 1996) and Fujii (Fujii et al., 1987) graphic methods. Subsequently, we delimited an area in the active region of the embryo (Figure 2) for each seed, where we performed a numerical analysis of the Absolute Values Difference (AVD) (Braga et al., 2011) at different collection times.

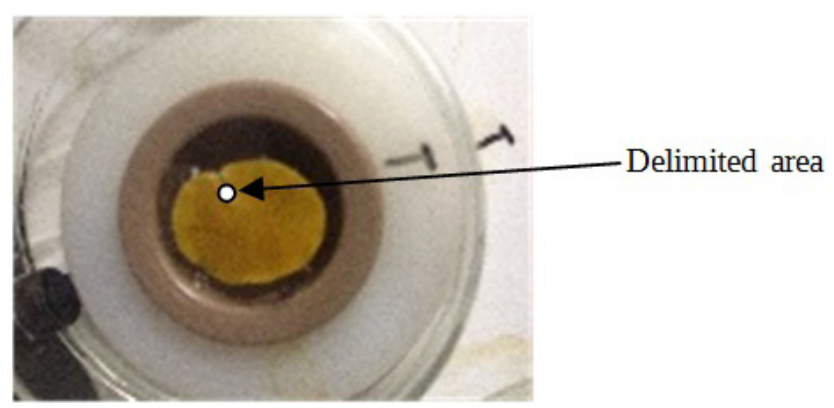

Figure 2: Delimited area in experiment 1 where the AVD values were obtained.

The AVD method equation that was used is:

$A V D=\sum_{k=1}^{N}\left|I_{k}-I_{k+1}\right|$

Where $I$ is the image at point $k$ of $N$ images collected.

To understand this high cellular activity presented in the first four hours of germination and at which preliminary moment this activity would already be high, we conducted a second experiment, illuminating the Angico-Vermelho seeds (green and mature) every 60 minutes during the first four hours of germination. The AVD was determined in three distinct areas of the seed: active area of the embryo; active area of the reserve material; and inactive area of the reserve material, denominated area 1 , area 2 , and area 3 , respectively (Figure 3 ). 


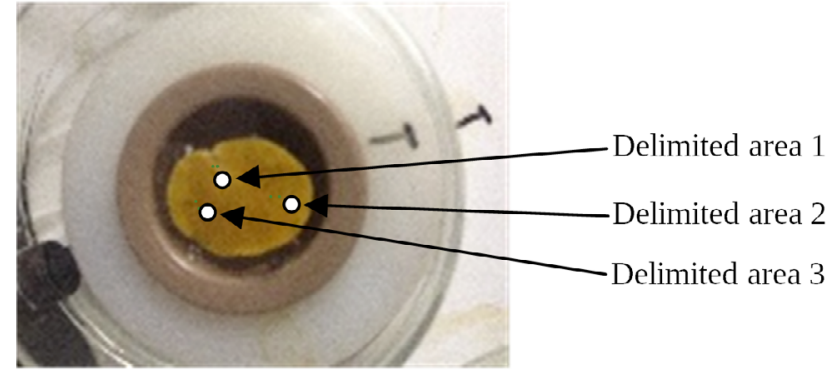

Figure 3: Delimited areas in experiment 2 where the AVD were obtained: active area of the embryo (area 1), active area of the reserve material (area 2), and inactive area of the reserve material (area 3).

\section{RESULTS AND DISCUSSION}

\section{Experiment 1}

The AVD values obtained in the active region of the embryo of the Angico-Vermelho seeds during the first 72 hours of germination, experiment 1, are shown in Figure 4.

Observed that the AVD values of the initial 72 hours of germination showed high cell activity in the embryo region since the first four hours of germination (Figure 4). This is within physiological normality given that, with the beginning of germination, the seeds first use the reserve material contained in the embryonic cells (Bewley and Black, 1994), thus, its biological activity is very high. According to Arizaga, Trivi, and Rabal (1999), the biospeckle activity is directly proportional to the activity level of the analyzed tissue, both by calculating the MI and ADL, indicating that high values represent high activity and vice versa. In this work, we used the AVD calculation given its greater sensitivity to the entire spectral composition, being able to provide complementary information about the analyzed phenomenon (Braga et al., 2011). This increase in activity observed during germination may be due to molecular and structural movements, such as cell division, stretching, organelle movement, and biochemical reactions (Braga, Pasqual and Cardoso, 2009). This complex internal movement, connected to metabolic activity, can be different considering the phase of development, the region analyzed, the water content, the level of deterioration, the temperature, and the position and intensity of the incident laser beam (Rabelo et al., 2005).

It appears that between the 24 to 48 hours of germination, the cellular activity was practically constant. However, a significant increase in the biological activity occurred at 72 hours of

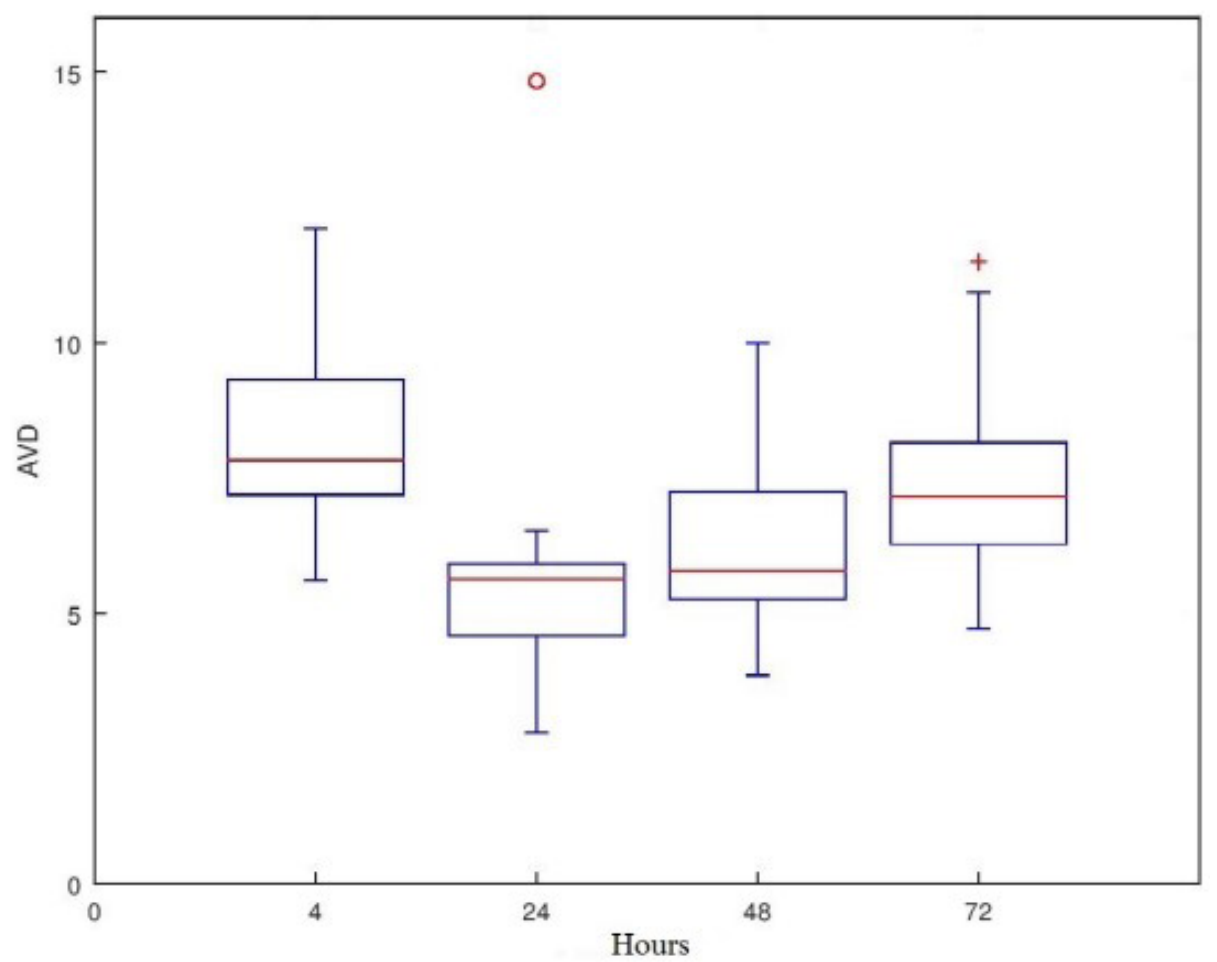

Figure 4: AVD values obtained by Biospeckle Laser in the active region of the embryo of AngicoVermelho seeds during the first 72 hours of germination. 
germination, mostly due to the proximity of the protrusion phase. The use of the biospeckle in an automated system, the carousel, allowed us to monitor the biological activity of eight samples at the same time, with each seed always remaining in the same position, that is, it was always illuminated in the same specific place, preventing each illumination from occurring in nearby regions. The AVD value presented in the first four hours of germination was higher than at other times (Figure 5) and may be due to the reserve material present in the embryo cells to supply the high demand for molecules necessary for energy production and structural components during cell lengthening and division, contributing largely for this high biological activity at the beginning of resumption; the tendency is that, over time, the biological activity of the axis slightly decreases due to the displacement time of the molecules. Recalling, the reserve material is now in the endosperm, requiring high biological degradation activity from the cells of the endosperm to supply the demand of the embryo region, in addition to the time of transport.

\section{Experiment 2}

We conducted a second experiment to understand this high cellular activity presented in the first four hours of germination. The AVD values obtained by the Biospeckle Laser in the active region of the embryo (area 1) of mature and green Angico-Vermelho seeds, over the first four hours of germination, are presented in Figure 5.

It appears that the AVD values obtained in the active embryo region (area 1) of mature seeds were higher than those of green seeds in all periods analyzed (Figure 5). The mature seeds are in the exact physiological stage to begin germination in maximum metabolic activity, while the green seeds are in a previous physiological stage, not fully able to begin germination, requiring time to reach this physiological stage conducive to fast germination. This ensures that the Biospeckle Laser technique with numerical analysis in AVD can be used to analyze germination regardless of the seed quality since this technique shows the physiological differences that occur over time without destroying the sample, that is, one being can be monitored over time.

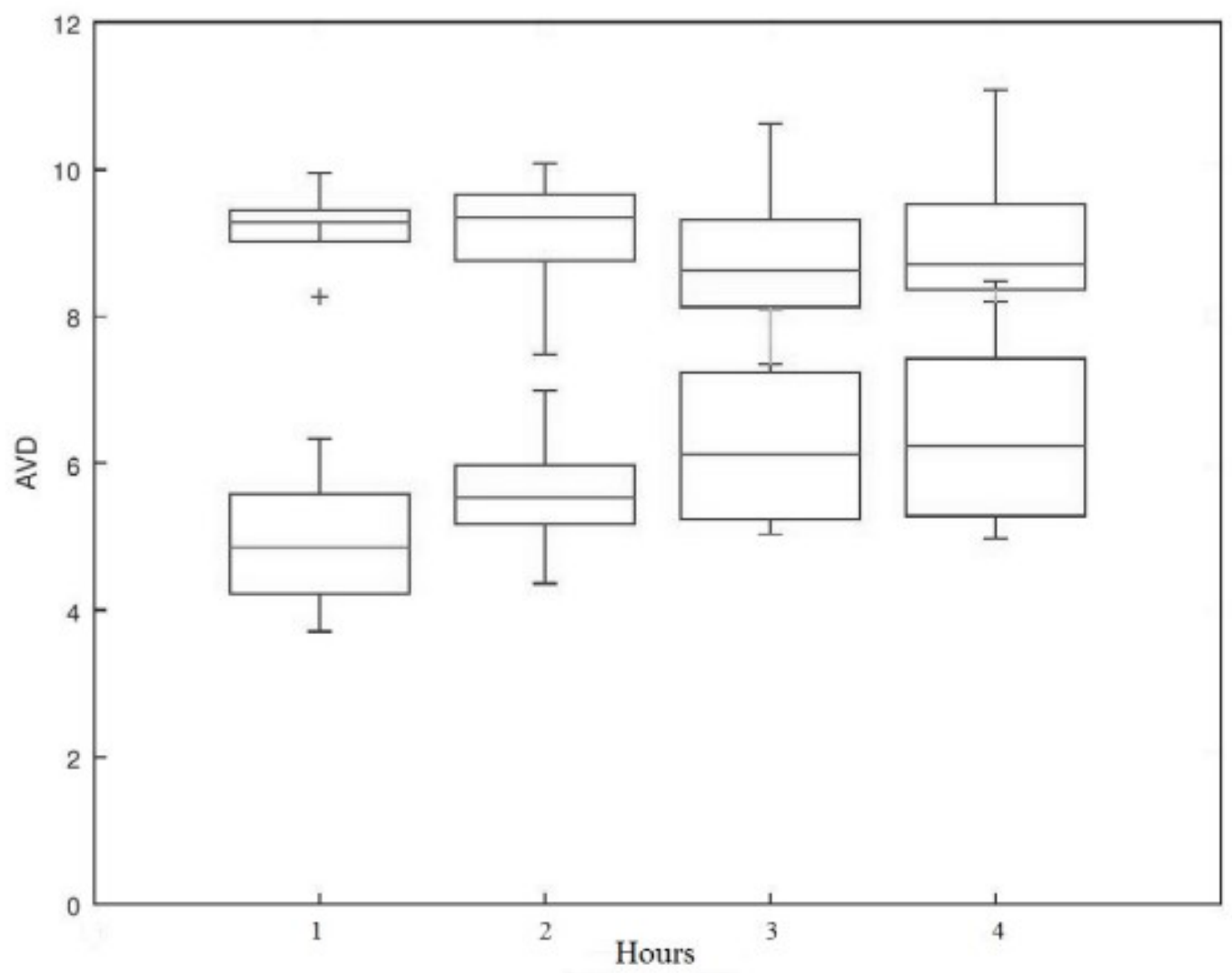

Figure 5: AVD values obtained by the Biospeckle Laser in the active region of the embryo of the mature and green Angico-Vermelho seeds during the first four hours of germination, at 60 minute intervals. 
Another pertinent fact is the expressive increase in the AVD values up to one hour of germination in mature seeds followed by stabilization, indicating that, with the Biospeckle Laser, it is possible to know the degree of germination viability of a seed in the first hour (Figure 5). Thus, we can select seeds with high germination power in the first hour of germination, avoiding long days of waiting for traditional germination tests. These results ensure that metabolic processes activated in the first hours of germination provide important information to explain the behavioral variations between seeds of different levels of vigor, indicating this optical technique when needing to demonstrate physiological differences in this short period of germination. We notice close values when comparing the AVD values obtained at four hours of germination of mature seeds of both experiments. It is worth remembering that in experiment 1 all the Angico-Vermelho seeds were mature.

Figure 6 shows the AVD values obtained by the Biospeckle Laser in the active area of the reserve material (area 2) of the mature and green
Angico-Vermelho seeds, over the first four hours of germination.

The active area of the reserve material of mature seeds showed AVD values much higher than those of green seeds in all periods analyzed, as well as in the active region of the embryo (Figure 6). When comparing the AVD values in area 1 with those of area 2 in the mature AngicoVermelho seeds, it appears that the reserve values were higher than the embryo values in all periods, that is, the reserve region was more physiologically active over the first four hours. However, the opposite is observed in green seeds, for which the embryo region was more than twice as active as that of the reserve and it has increased over time. This can be explained by the fact that the mature seeds are physiologically ready, the embryo already required more molecules for its development. In the green seeds, the embryo region was still little active and, consequently, required fewer molecules from the reserve region, requiring no high physiological activity in the active area of the reserve material, therefore its AVD value was low and practically constant.

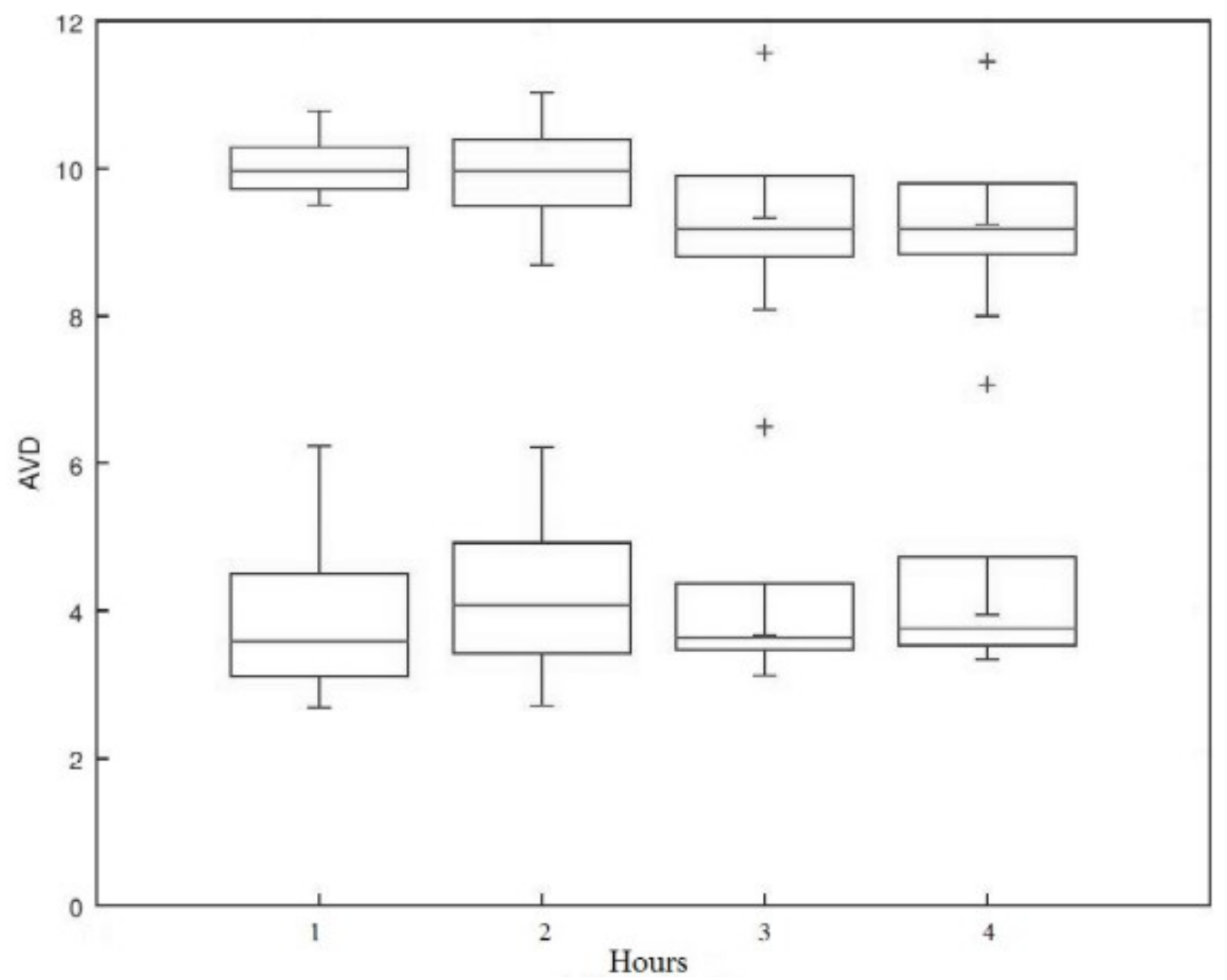

Figure 6: AVD values obtained by the Biospeckle Laser in the active region of the reserve material of the mature and green Angico-Vermelho seeds during the first four hours of germination, at 60-minute intervals. 
Note that there was no increase in biological activity in the active region of the reserve material in mature seeds, but not in green seeds. It is worth remembering that, at the beginning of the imbibition, the speed of water entry into the reserve material is much lower than in the embryo, thus justifying this non-elevation of the AVD shown in Figure 6.

The AVD values obtained by the Biospeckle Laser in the inactive region of the embryo (area 3) of mature and green Angico-Vermelho seeds, over the first four hours of germination are presented in Figure 7.

Note that the AVD values obtained for mature seeds were always higher than those of green seeds in all periods analyzed (Figure 7). Also, for the mature seeds, the AVD values up to two hours of germination were higher than those reported in the third and fourth hours of germination. With green seeds, there was little change in the AVD value during this period. This confirms that the mature seeds were in the exact physiological stage to begin germination, which does not occur in green seeds. It appears that the AVD values obtained in the inactive region of the embryo (area 3) were lower than those obtained in areas 1 and 2 (Figures 5, 6, and 7). This shows that the Biospeckle Laser technique has the capacity to reveal that the regions of the reserve material undergo degradation at different speeds and at different times, where this speed is connected to the distance to the aleurone layer and the need for the reserve cells to supply the embryonic demand (Figures 5, 6, and 7). Braga et al. (2001) showed the sensitivity of identifying areas with different levels of activity in corn seeds, which are the endosperm and the embryonic axis, corroborating the results found in this work. During the imbibition with coffee seeds, higher activity was also observed in the region of the embryonic axis when compared to cotyledons, indicating a relationship with embryo growth and metabolic activity (Vivas, 2016).

As already evidenced by Braga Junior (2001), the Biospeckle Laser method is efficient to identify differences between high vigor soybeans and dead seeds. Similar results were found by Fracarolli et al. (2011) when

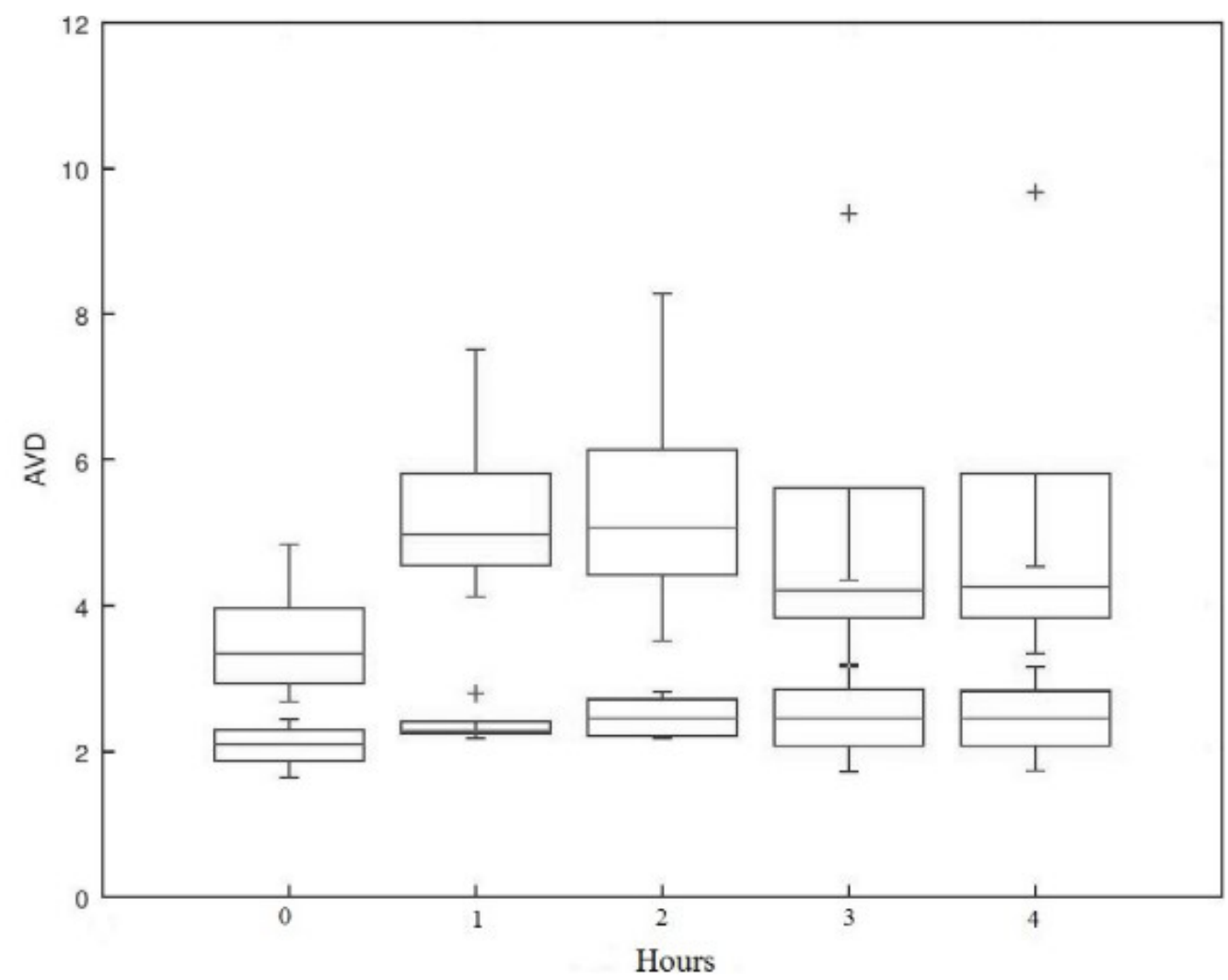

Figure 7: AVD values obtained by the Biospeckle Laser in the inactive region of the reserve material of the mature and green Angico-Vermelho seeds during the first four hours of germination, at 60-minute intervals. 
correlating the germinative potential of Tabebuia heptaphylla (purple ipe) seeds with Moment of Inertia (MI) values, where seeds of greater physiological potential showed higher mean MI values, due to greater metabolic activity when compared to seeds with low germination potential. Vivas (2016) also reported a positive correlation between Biospeckle Laser activity and the quality of coffee seeds and the tetrazolium test, also showing higher rates for seeds that originated normal seedlings during germination.

Finally, the results obtained in these experiments ensure that the Biospeckle Laser technique with numerical AVD analysis can be used to analyze the germination of seeds already the first hours of germination, dispensing with traditional methods. This technique also allows to reveal the different physiological speeds in each region and at different times. As the samples are not destroyed, this technique allows the same seed to be monitored during its development in real time and then taken to the seedling nursery to become a seedling.

\section{CONCLUSIONS}

The results obtained in these experiments ensure that the Biospeckle Laser technique with numerical AVD analysis can be used to analyze the germination of of A. colubrina already in the first 4 hours of germination, dispensing with traditional methods. This technique allows to study the seed germination in different regions and at different times.

\section{ACKNOWLEDGMENTS}

This work was partially financed by CAPES, FAPEMIG, CNPq, and FINEP in Brazil.

\section{REFERENCES}

ARMSTRONG, W. et al. Measuring and interpreting respiration critical oxygen pressures in roots. Annals of Botany, 103(2): 281-293, 2009.

ALTSCHUL, S. V. R. A taxonomic study of de Genus Anadenanthera. Contributions from the Gray Herbarium of Harvard University. JSTOR, (193):365, 1964.
BEWLEY, J. D.; BLACK, M. Seeds: physiology of development and germination. New York: Plenum, 1994. 445p.

BRADFORD, K. J.; CÔME, D.; CORBINEAR, F. Quantifying the oxygen sensitivity of seed germination using a population-based threshold model. Seed Science Research, 17(1): 33-43, 2007.

BRAGA, R. A. et al. Potencial do biospeckle laser para avaliação da viabilidade de sementes. Ciência e Agrotecnologia, 25(3):645-649, 2001.

BRAGA, R. A. et al. Assessment of seed viability by laser speckle techniques. Biosystems Engineering, 86(3):287-294, 2003.

BRAGA JÚNIOR, R. A. et al. Detection of fungi in beans by the laser biospeckle technique. Biosystems Engineering, 91(4):465-469, 2005.

BRAGA, R. A.; D., L.; PASQUAL. M.; CARDOSO, R. R. Live biospeckle laser imaging of root tissues. European Biophysics Journal, 38(5):679-686, 2009.

BRAGA, R. A. et al. Evaluation of activity through dynamic laser speckle using the absolute value of the diferences. Optics Communications, 284(2):646-650, 2011.

BRIERS, J. D.; WEBSTER, S. Laser speckle contrast analysis LASCA: A nonscanning, full-field technique for monitoring capillary blood flow. Journal of Biomedical Optics, 1(2):174-179, 1996.

EATON, J. W. et al. GNU Octave version 4.0.0 manual: a high-level interactive language for numerical computations. Avaiable at: http:// www.gnu.org/software/octave/doc/interpreter. 2015.

FRACAROLLI, J. A. et al. Ipe (Tabebuia impetiginosa) seed quality evaluation by means of laser biospeckle. Selskostopanska Tekhnika, 47(1):73-78, 2010.

FONSECA, S. C. L.; FREIRE, H. B. Recalcitrants seeds: post-harvest problems. Bragantia, 62(2):297303, 2003.

FUJII, H. et al. Evaluation of blood flow by laser speckle image sensing. Applied Optics, 26(24):5321$5325,1987$. 
KOSZO, C. R. R.; RINALDI, M. C. S.; BARBEDO, C. J. Germinação de sementes de Erythrina speciosa Andr., Eugenia brasiliensis Lam. e Cucumis satious L. em meio ácido. Hoehnea, 34(3):271-282, 2007.

LEE, C. et al. Optical Sensing Method for Screening Disease in Melon Seeds by Using Optical Coherence Tomography. Sensors, 11(10):9467-9477, 2011.

LORENZI, H. Árvores brasileiras: manual de identificação e cultivo de plantas arbóreas nativas do Brasil. 6. ed. Nova Odessa: Intituto Plantarum. 2014. 384p.

MACHADO, C. F.; CÍCERO, M. S. Metodologia para a condução do teste de germinação e utilização de raios- $X$ para a avaliação da qualidade de sementes de aroeira-branca (Lithraea molleoides (Vell.) Engl.). Informativo Abrates, 12(123):28-34, 2002.

MEGLINSKI, I. V.; BURANACHAI, C.; TERRY, L. A. Plant photonics: Application of optical coherence tomography to monitor defects and rots in onion. Laser Physics Letters, 7(4):307-310. 2010.

MONTEIRO, J. M. et al. Teor de taninos em três espécies medicinais arbóreas simpátricas da caatinga. Revista Árvore, 29(6):999-1005, 2005.

MOREIRA, M.F. B. etal. Caracterização da transmissão da luz laser em semente de feijão (Phaseolus vulgaris L.). Revista Brasileira de Produtos Agroindustriais, 4(2):119-125, 2002.

MOURA, M. L. S. et al. Biospeckle as tool auxiliary in evaluation dormancy overcoming araçá-boi seeds. International Journal of Agricultural Research and Reviews, 3(7):411-420, 2015.

NASCIMENTO, A. L. et al. Development of a Model for the Biospeckle Applied to Analise Been Seed (Phaseolus Vulgaris L.). Ciência e Agrotecnologia, 31(2):456-461, 2007.

PAES, J. B. et al. Avaliação do potencial tanífero de seis espécies florestais de ocorrência no semi-árido brasileiro. CERNE, 12(3):232-238, 2006.

PARISI, J. J. D. et al. Patologia de sementes florestais: danos, detecção e controle, uma revisão. Summa Phytopathologica, 45(2):129-133, 2019.
PEIXOTO, L. S. et al. Maize Seeds Submitted to Thermotherapy and Analyzed by Dynamic Speckle. Journal of Agricultural Science and Technology B, 8(2):115-121, 2018.

RABAL, H.; BRAGA, R. A. Dynamic laser speckle and applications. New York: CRC, 2008. 304 p.

RABELO, G. F.; BRAGA JR., R. A.; FABBRO, I. M. D. Laser speckle techniques in quality evaluation of orange fruits. Revista Brasileira de Engenharia Agrícola e Ambiental, 9(4):570-575, 2005.

RODRIGUES, S. et al. Efeito da umidade na determinação da atividade biológica de sementes de feijão (Phaseolus vulgaris L.), utilizando imagens de speckle dinâmico. Revista Brasileira de Armazenamento, 30(2):135-139, 2005.

RODRIGUES, S. et al. Aplicação do speckle dinâmico na análise de sementes de feijão (Phaseolus vulgaris L). Revista Brasileira de Produtos Agroindustriais, 9(2):119-124, 2007.

SILVA, N. C. B. et al. Uso de plantas medicinais na comunidade quilombola da Barra II-Bahia, Brasil. Boletín Latinoamericano y del Caribe de Plantas Medicinales y Aromáticas, 11(5):435-453, 2012.

VIEIRA R. D.; CARVALHO, N. M. Testes de vigor em sementes. Jaboticabal: FUNEP. p. 1-30. 1994.

VIVAS, P. G. et al. Biospeckle activity in coffee seeds is associated non-destructively with seedling quality. Annals of Applied Biology, 170(2):141-149, 2016.

XIN, X. et al. A real-time, non-invasive, micro-optrode technique for detecting seed viability by using oxygen influx. Scientific Reports, 3(3057):1-6, 2013.

ZDUNEK, A. et al. The biospeckle method for the investigation of agricultural crops: a review. Optics and Lasers in Engineering, 52(1):276-285, 2014. 